\title{
Expert System to Determine Learning Style Using Forward Chaining Method
}

\author{
Dela Yunita Cahya, Shinta Oktaviana \\ Study Program of Informatics Engineering \\ Dela.yunita66@gmail.com,Shinta.oktaviana@tik.pnj.ac.id
}

Diterima: 1 April 2018. Disetujui: 20 April 2018. Dipublikasikan: Mei 2018

\begin{abstract}
The expert system of learning modalities determination is a system that adopts the knowledge of an educational psychologist in determining the learning modalities that are appropriate to the child's personality. This expert system is made by forward chaining method and uses the expert Certainty Factor (CF) value. The purpose of this expert system is to prove that forward chaining method can be implemented in making this expert system. Furthermore, expert system can provide benefits to assist an educational psychology in Bahana Psikologi Pelangi (BPP) in performing the determination test of visual modalities, auditory or kinesthetic. Data obtained by conducting interviews and based on questionnaires in BPP in determining a person's learning modalities. Implementation of forward chaining method with the implementation of $C F$ value is important in determining the conclusion of modalities and suggestions that will be recommended. The end result of this expert system is the highest CF value of each modality. Tests on the system performed by comparing the conclusions of modalities on expert systems with the conclusion of modalities on the calculation of manual questionnaires in BPP. Based on the 53 questionnaires used, there are 42 data showing the same modalities conclusion with manual process, while 11 of them show different result because of the priority of $C F$ value in expert system.
\end{abstract}

Keywords: certainty factor (CF), expert system, forward chaining, learning style.

\section{INTRODUCTION}

According to Kamus Besar Bahasa Indonesia (KBBI) Online, learning is trying to obtain intelligence or knowledge. The meaning of teaching according to KBBI is instructive. This means that there role as a facilitator, the teacher and the parent. Thus, teaching and learning can be interpreted as an activity where there is a facilitator who provides a lesson, the goal for children to acquire knowledge.

Surely all parents expect their children to follow the process of teaching and learning well. So with that child will easily understand the lessons that have been taught. A good understanding of learning can be seen from the success of learning, like to work on the problems of the evaluation study, get good grades and so forth.

But the problem is, not all children are able to cope well. If this is the case, then the child will be lazy to learn. In addition, this will also cause the child's difficulty in understanding. Therefore, it is very important for parents and teachers to determine the cause. As one of the causes of these problems can occur because of a parent or teacher does not know how the learning style that suits the child.

Actually, learning styles or learning modality children consist of three types, namely, visual, auditory, and kinesthetic. Type of learning styles between each other have different characteristics. Basically, almost everyone has all three types of learning styles or learning modality, but there is one dominant type in a person. Provide appropriate learning methods will be made easier if the dominant types of learning styles in children can be known. As forinformation, parents or teachers can perform tests to determine the type of the child's learning style. The test should be conducted with the assistance of a skilled expert in the field, such as children's education psychologist. Bahana Psychology Pelangi (BPP) Consultant, is one of the children's education bureau in the city of Depok. Bureau which stands since April 11, 2015, has been nearly two years of actively working with private schools as a facilitator psychologist. Consultant BPP bureau usually asked by schools to conduct tests determination of multiple intelligences, interests and talents, and one of them is the determination of learning style.

A test given by the BPP bureau in the form of a questionnaire. The questionnaire answers will then be calculated (scoring) and the results are used as a reference for determining the learning style. The manual process is considered less efficient and effective. If the person taking the test is more than 50 ( $>50$ ), the calculation of (scoring) can take place over 2 days. In addition, if the person taking the test is more than 50 , the budget expenditure required BPP in conducting this test also rated quite high. As for the budgetary costs such as the cost of 
paper, ink, and incentive services biasya someone who helps in performing calculations (Scoring) test. Therefore, in order to process this BPP operational at the bureau can take place effectively and efficiently, it needed an expert system that can determine the type of learning style that suits the child's personality. So the experts in determining the child's learning style can be easily done.

One method of expert system used to generate conclusions and criteria: Forward Chaining method. Forward Chaining is a strategy to predict or find a solution to a problem that starts from a set of known facts and then lowering the new fact that the premise is based on the rules fit with the known facts and the process becomes faster and optimized.

\section{LITERATURE REVIEW}

\section{A. Artificial Intelligence (AI)}

Artificial Intelligence (AI) is one field of knowledge about the design of intelligent machines. Most people do not know about what the intelligent machines may suppose that the same intelligent machine with a robot. But the meaning of artificial intelligence is actually not a robot. Nowadays the concept of artificial intelligence is understood as a branch of the IT field. The subject of this branch of science is the study of how human intelligence activity.

Rich and Knight [1], stated that the artificial intelligence (AI) as a study of how to make computers do things at this point can be done better by humans. According to Winston and Prendergast [2], the purpose of artificial intelligence are:

1) Creating a smarter machine (main goal)

2) Understand what intelligence (scientific goal)

3) Make the engine more helpful (entrepreneurial objectives)

\section{B. Expert System}

An expert system is a branch of artificial intelligence (Artificial Intelligence).Expert systems are intelligent computer program that uses knowledge and inference procedures to solve problems that are difficult and require an expert to solve it [3]. In addition, other opinion means that the expert system is a system designed to be able to mimic the skills that experts in answering questions and solving problems. Expert systems will provide a solution to a problem that is obtained from dalog by users. With the help of someone who is not an expert system dapt expert answered questions. Solve problems and make decisions ang usually done by an expert [4].

\section{Basic Concepts of Expert Systems}

To understand more clearly about expert systems, in addition to understanding must be understood, users also need to know how the basic concept of the expert system. The basic concept of expert system according to T.Sutojo includes six of the following, namely: expertise, experts, transfer of expertise, inference, rules (Rule), the ability to explain.[4]

\section{Structure of Expert System}

The most important structure of an expert system, there are two parts, the development environment (development environtment) and environmental consultancy services (consultation environtment). In accordance with each type of environment, development environment used by developers to build an expert system components and define the knowledge base of expert knowledge. Instead, the environmental consultations will be used by non-expert users to consult. Non-expert users can use part of this environment to gain knowledge and advice information such as real consultation with an expert. Figure 1 will show the components that are important in an expert system [4].

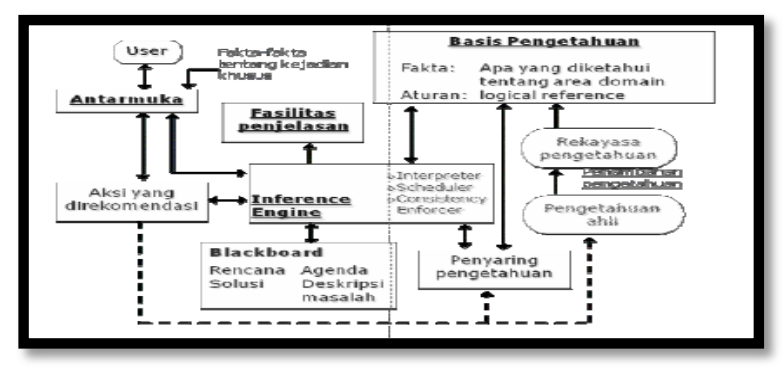

Figure 1. Expert System Structure

\section{E. Rule As Engineering Knowledge Representation}

An expert system commonly referred to as a knowledge based system (knowledge based systems) that use the knowledge to hold the knowledge of the problems and later in encoded from several facts, rules, procedures, relationships and so forth [5]. The quality of the expert system relies on the knowledge base and the quality of the knowledge base that relies on knowledge engine. The knowledge base is treated using a set of rules and use a list variable [5].

T. Sutojo states that each rule consists of two parts, the IF section is referred to as evidence (facts) and THEN part called the hypothesis or conclusion. As examples of Rule syntax is as follows:

$$
\text { IF } \mathrm{E} \text { THEN } \mathrm{H}
$$


E: Evidence (Factual) existing

$\mathrm{H}$ : Hypothesis or the conclusions.

\section{F. Techniques Inference}

In the rule-based expert systems, domain knowledge represented in an aggregated form of IFTHEN rules, while the data represented in a collection of facts about current events [6]. The inference engine will process rule stored in the knowledge base and the facts that are stored in the database with matching procedure. Rule will be executed if the part IF (condition) of the rule to fit the facts, then part THEN (action) will be put in the database as new facts are added. There are two types of inference techniques to implement the existing rules, the inference technique is the technique of forward chaining and backward chaining inference techniques. In the following discussion will only focus on the forward chaining technique.

\section{G. Forward Chaining}

Forward Chaining is one of the type inference which runs a search of a problem to find a solution. This inference method using a search technique that starts from the observation of the input information or hypothesis then the conclusion drawn and ready to be sought from the information currently available [3].

An expert system rule formulated with "IF A THEN B" where A is a set of conditions on the data and $\mathrm{B}$ is a set of instructions to be executed when the rule is executed. Then rule on the IF (condition) will be matched with existing facts. If the rule is executed, then a new fact will be stored into the database [7]. Matching rule always starts from the top. Each rule can only be executed once. Matching process will stop if there is no rule that should be executed.

\section{H. Certainty Factor}

According to Turban in a journal entitled "Sistem Pakar Mendiagnosa Penyakit Demam Berdarah Menggunakan Metode Certainty Factor". The certainty factor specifies belief in an event (fact or hypothesis) based on evidence or expert judgment. Certainty factor uses a value to assume an expert's degree of confidence in a data.

$$
\mathrm{CF}[\mathrm{H}, \mathrm{E}]=\mathrm{MB}[\mathrm{H}, \mathrm{E}]-\mathrm{MD}[\mathrm{H}, \mathrm{E}]
$$

- $\mathrm{CF}(\mathrm{H}, \mathrm{E})=$ certainty factor hypothesis affected by the evidence e is known with certainty

- $\operatorname{MB}(\mathrm{H}, \mathrm{E})=$ measure of belief against hypothesis $\mathrm{H}$, if given evidence $\mathrm{E}$ (between 0 and 1)
- $\operatorname{MD}(\mathrm{H}, \mathrm{E})$ = measure of disbelief against evidebce $\mathrm{H}$, if given evidance $\mathrm{E}$ (between 0 and 1)

Certainty factor for single premise rule

$\mathrm{CF}[\mathrm{H}, \mathrm{E}] 1=\mathrm{CF}[\mathrm{H}] * \mathrm{CF}[\mathrm{E}]$

Certainty Factor for rules with similar conclusions (similarly concluded rules):

$$
\begin{aligned}
& \mathrm{CF} \text { combineCF }[\mathrm{H}, \mathrm{E}] 1,2=\mathrm{CF}[\mathrm{H}, \mathrm{E}] 1+\mathrm{CF}[\mathrm{H}, \mathrm{E}] 2 * \\
& {[1 \mathrm{CF}[\mathrm{H}, \mathrm{E}] 1]}
\end{aligned}
$$

$$
\begin{aligned}
& \text { CFcombineCF[H,E }] \text { old }, 3=\mathrm{CF}[\mathrm{H}, \mathrm{E}] \mathrm{old}+\mathrm{CF}[\mathrm{H}, \mathrm{E}] 3 *( \\
& 1 \mathrm{CF}[\mathrm{H}, \mathrm{E}] \text { old }]
\end{aligned}
$$

\section{Modality or Learning Styles}

According to Dunn and Dunn, modality or learning style is the way a person in concentrate, absorb, process, and controls the information that is new or has long acquired (Norah Md Noor, 2014). Modality or learning style is usually defined as a characteristic cognitive, social and behavioral physiological run relatively stable indicators of how a person receives, interacts and responds to the learning environment [8].

The types of modalities or styles of learning known to generally be divided into three types, namely visual, auditory and kinesthetic. Below will be explained the modalities by Leny Hartati and characteristics of each type of learning modality quoted thesis Siti Rohani entitled "Applications Define the modalities or the Child Learning Styles":

\section{1) Visual}

These learning styles rely on learning activities to the subject matter he sees. In this visual learning style plays an important role in how learning is visual. The mind map / concept can be a great tool for visual learners because they learn best when they started with the "overall picture", do a general review megenai materials.

\section{2) Auditory}

These learning styles rely on learning activities to the subject matter heard. Auditory learners prefer to record on tape rather than recorded, because they like to listen to repetitive information.

3) Kinesthetic

This learning style learning activities relying on the movement. The kinesthetic learners prefer to learn through movement, and is best to memorize the information to associate the movement with every fact. They prefer to sit on the floor and spread the work around them. 


\section{DESIGN AND REALIZATION}

Making this expert system is divided into three stages, namely:

1) initialization phase

2) the stage of analysis and design;

3) implementation and testing phase.

For more details notice Figure 2. The first stage is the initialization phase. At this stage, the problem identification was done by interviewing the child psychology expert on one of the children's education psychology consultancy in Depok, Bahana Psikologi Pendidikan (BPP). Identification of problems is also done through literature studies of books, journals and other scientific works related to child talent. After that an analysis of the results of the problem identification to determine the purpose and scope of this study.

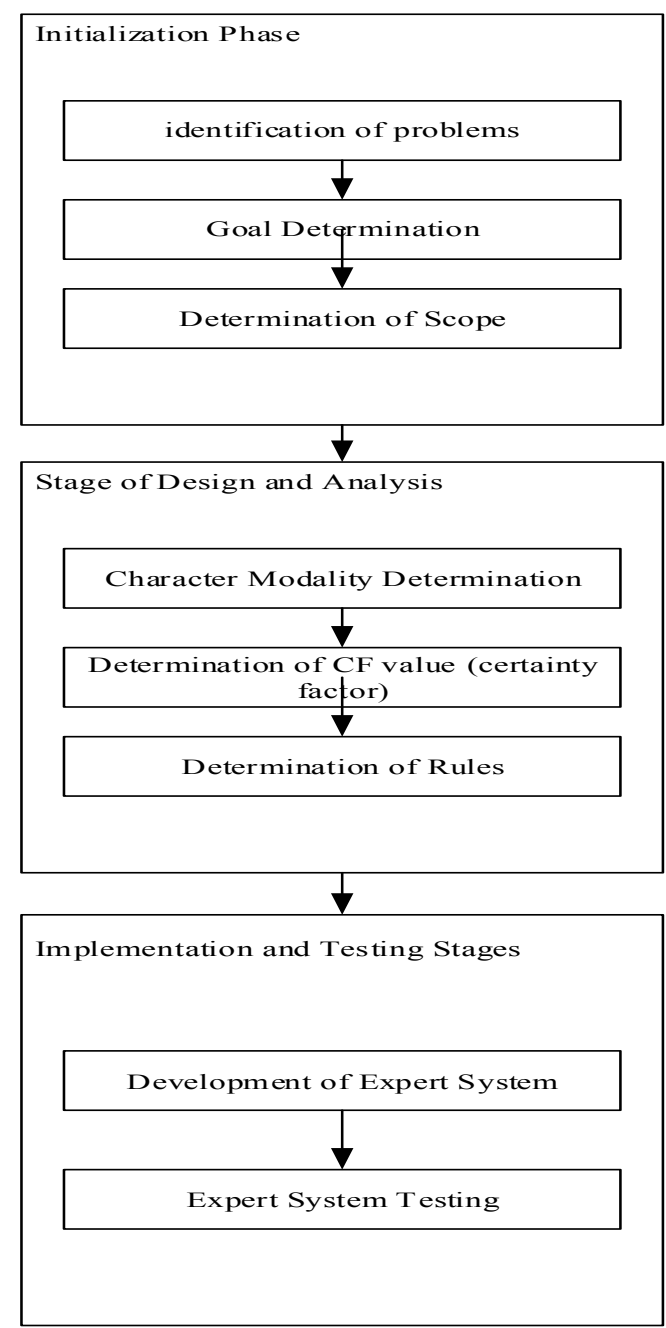

Figure 2. Design Methodology

The second stage is the analysis and design phase. The stages of analysis and design are as follows:

\section{a.) Character Determination}

At this stage analyzed the characters of the three learning styles, namely auditory and kinesthetic visuals. Each style of learning has a different character. Members can find out their own learning styles after consulting on the consultation page. The consultation page views can be seen in Figure 3.

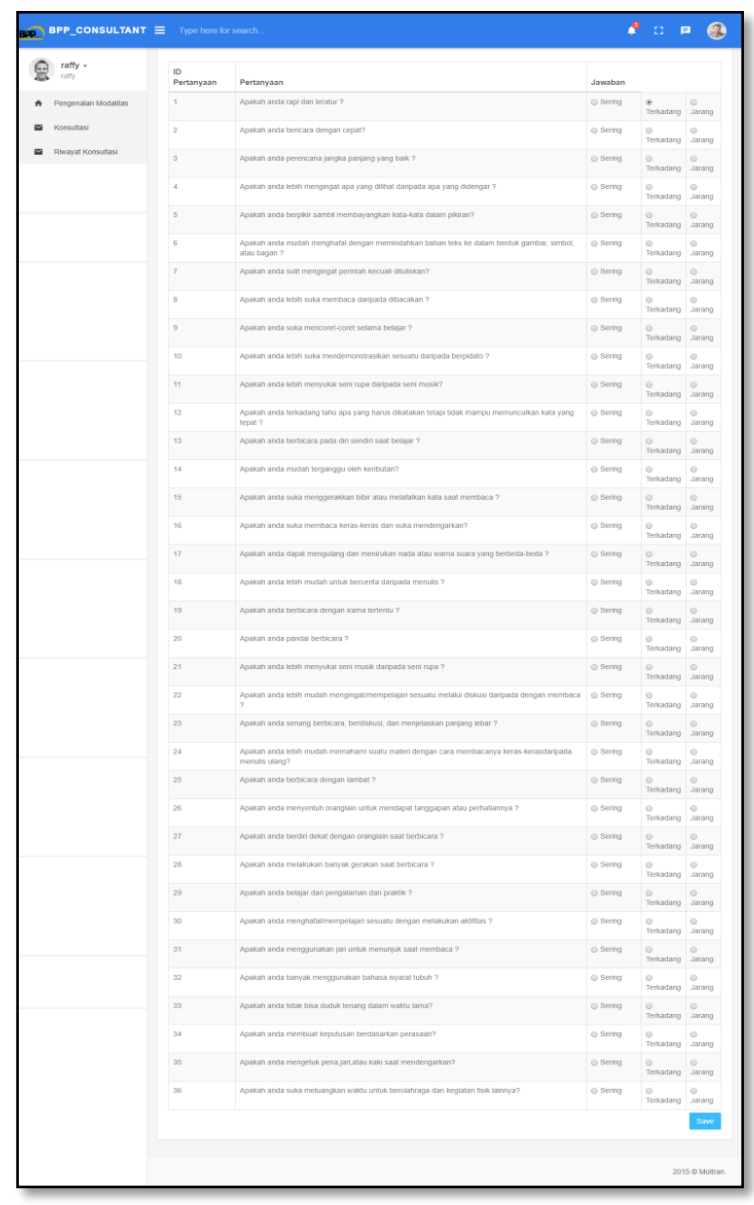

Figure 3. Impementation Consultation Page

Users must answer 36 questions contained on the consultation page, where 36 questions are repesent of the character of each learning style. Each question has 3 different answers and weights of answers. The choice of answers and their weight can be seen in Table 1 .

\section{TABLE 1. ANSWER OPTIONS AND ANSWER WEIGHT}

\begin{tabular}{|l|c|}
\hline \multicolumn{1}{|c|}{ Pilihan Jawaban } & Bobot Jawaban \\
\hline Sering & 0.6 \\
\hline Terkadang & 0.2 \\
\hline Jarang & 0 \\
\hline
\end{tabular}




\section{b.) Determination of CF Value}

After the character of each learning style has been determined with the expert (educational psychology), then the CF Value can be determined with the expert, the $\mathrm{CF}$ value of each learning style character is as follows:

TABLE 2. CHARACTER CF VALUE

\begin{tabular}{|c|c|c|}
\hline Id_pertanyaan & Pertanyaan & $\begin{array}{l}\text { Nilai } \\
\mathrm{CF}\end{array}$ \\
\hline 1 & Apakah anda rapid an teratur? & 0.8 \\
\hline 2 & $\begin{array}{l}\text { Apakah anda bericara dengan } \\
\text { cepat? }\end{array}$ & 0.8 \\
\hline 3 & $\begin{array}{l}\text { Apakah anda perencana jangka } \\
\text { panjang yang baik? }\end{array}$ & 0.4 \\
\hline 4 & $\begin{array}{l}\text { Apakah anda lebih mengingat } \\
\text { apa yang dilihat daripada apa } \\
\text { yang didengar? }\end{array}$ & 1 \\
\hline 5 & $\begin{array}{l}\text { Apakah anda berpikir sambil } \\
\text { membayangkan kata-kata dalam } \\
\text { pikiran? }\end{array}$ & 0.8 \\
\hline 6 & $\begin{array}{l}\text { Apakah anda mudah menghafal } \\
\text { dengan memindahkan bahan } \\
\text { teks ke dalam bentuk gambar, } \\
\text { simbol, atau bagan? }\end{array}$ & 1 \\
\hline 7 & $\begin{array}{l}\text { Apakah anda sulit mengingat } \\
\text { perintah kecuali dituliskan? }\end{array}$ & 1 \\
\hline 8 & $\begin{array}{l}\text { Apakah anda lebih suka } \\
\text { membaca daripada dibacakan? }\end{array}$ & 1 \\
\hline 9 & $\begin{array}{l}\text { Apakah anda suka mencoret- } \\
\text { coret selama belajar? }\end{array}$ & 1 \\
\hline 10 & $\begin{array}{l}\text { Apakah anda lebih suka } \\
\text { mendemonstrasikan sesuatu } \\
\text { daripada berpidato? }\end{array}$ & 1 \\
\hline 11 & $\begin{array}{l}\text { Apakah anda lebih menyukai } \\
\text { seni rupa daripada seni musik? }\end{array}$ & 1 \\
\hline 12 & $\begin{array}{l}\text { Apakah anda terkadang tahu apa } \\
\text { yang harus dikatakan tetapi } \\
\text { tidak mampu memunculkan } \\
\text { kata yang tepat? }\end{array}$ & 1 \\
\hline 13 & $\begin{array}{l}\text { Apakah anda berbicara pada diri } \\
\text { sendiri saat belajar? }\end{array}$ & 0.6 \\
\hline 14 & $\begin{array}{l}\text { Apakah anda mudah terganggu } \\
\text { oleh keributan? }\end{array}$ & 0.6 \\
\hline 15 & $\begin{array}{l}\text { Apakah anda suka } \\
\text { menggerakkan bibir atau } \\
\text { melafalkan kata saat membaca? }\end{array}$ & 0.8 \\
\hline 16 & $\begin{array}{l}\text { Apakah anda suka membaca } \\
\text { keras-keras dan suka } \\
\text { mendengarkan? }\end{array}$ & 1 \\
\hline 17 & $\begin{array}{l}\text { Apakah anda dapat mengulang } \\
\text { dan menirukan nada atau warna } \\
\text { suara yang berbeda-beda? }\end{array}$ & 1 \\
\hline 18 & $\begin{array}{l}\text { Apakah anda lebih mudah untuk } \\
\text { bercerita daripada menulis? }\end{array}$ & 1 \\
\hline 19 & $\begin{array}{l}\text { Apakah anda berbicara dengan } \\
\text { irama tertentu? }\end{array}$ & 1 \\
\hline 20 & Apakah anda pandai berbicara? & 1 \\
\hline 21 & $\begin{array}{l}\text { Apakah anda lebih menyukai } \\
\text { seni musik daripada seni rupa? }\end{array}$ & 1 \\
\hline 22 & $\begin{array}{l}\text { Apakah anda lebih mudah } \\
\text { mengingat/mempelajari sesuatu } \\
\text { melalui diskusi daripada dengan } \\
\text { membaca? }\end{array}$ & 1 \\
\hline 23 & $\begin{array}{l}\text { Apakah anda senang berbicara, } \\
\text { berdiskusi, dan menjelaskan } \\
\text { panjang lebar? }\end{array}$ & 1 \\
\hline
\end{tabular}

\begin{tabular}{|c|c|c|}
\hline 24 & $\begin{array}{l}\text { Apakah anda lebih mudah } \\
\text { memahami suatu materi dengan } \\
\text { cara membacanya keras- } \\
\text { kerasdaripada menulis ulang? }\end{array}$ & 0.8 \\
\hline 25 & $\begin{array}{l}\text { Apakah anda berbicara dengan } \\
\text { lambat ? }\end{array}$ & 1 \\
\hline 26 & $\begin{array}{l}\text { Apakah anda menyentuh } \\
\text { oranglain untuk mendapat } \\
\text { tanggapan atau perhatiannya? }\end{array}$ & 0.8 \\
\hline 27 & $\begin{array}{l}\text { Apakah anda berdiri dekat } \\
\text { dengan oranglain saat berbicara } \\
\text { ? }\end{array}$ & 0.8 \\
\hline 28 & $\begin{array}{l}\text { Apakah anda melakukan banyak } \\
\text { gerakan saat berbicara? }\end{array}$ & 0.8 \\
\hline 29 & $\begin{array}{l}\text { Apakah anda belajar dari } \\
\text { pengalaman dan praktik? }\end{array}$ & 1 \\
\hline 30 & $\begin{array}{l}\text { Apakah anda } \\
\text { menghafal/mempelajari sesuatu } \\
\text { dengan melakukan aktifitas? }\end{array}$ & 1 \\
\hline 31 & $\begin{array}{l}\text { Apakah anda menggunakan jari } \\
\text { untuk menunjuk saat membaca } \\
\text { ? }\end{array}$ & 1 \\
\hline 32 & $\begin{array}{l}\text { Apakah anda banyak } \\
\text { menggunakan bahasa isyarat } \\
\text { tubuh? }\end{array}$ & 0.8 \\
\hline 33 & $\begin{array}{l}\text { Apakah anda tidak bisa duduk } \\
\text { tenang dalam waktu lama? }\end{array}$ & 1 \\
\hline 34 & $\begin{array}{l}\text { Apakah anda membuat } \\
\text { keputusan berdasarkan } \\
\text { perasaan? }\end{array}$ & 1 \\
\hline 35 & $\begin{array}{l}\text { Apakah anda mengetuk } \\
\text { pena,jari,atau kaki saat } \\
\text { mendengarkan? }\end{array}$ & 0.8 \\
\hline 36 & $\begin{array}{l}\text { Apakah anda suka meluangkan } \\
\text { waktu untuk berolahraga dan } \\
\text { kegiatan fisik lainnya? }\end{array}$ & 0.8 \\
\hline
\end{tabular}

\section{c.) Determination of Rules}

Character and $\mathrm{CF}$ values for each character have been determined, then the next step is to set rules to distinguish the 36 questions on the consultation page. Of the 36 questions can be divided into 3 categories, the first 12 questions represent visual style learning questions, the next 12 questions represent the auditory question and the last 12 questions are representative kinesthetic questions. Therefore, rules are needed to distinguish 3 categories of questions from the learning style. The implementation of these rules using forward chaining method. Rules can be seen in Table 3.

\begin{tabular}{|c|l|}
\multicolumn{2}{|c|}{ TABLE 3. RULES OF EXPERT SYSTEM } \\
\hline Rule ke-x & \multicolumn{1}{|c|}{ Deskripsi Rule } \\
\hline R1 & $\begin{array}{l}\text { If } \\
\text { Id_pertanyaan= “1, 2, 3, 4, 5, 6, 7, 8, 9, } \\
10,11,12 " \\
\text { Then [Kesimpulan] = "CF Visual” }\end{array}$ \\
\hline R2 & $\begin{array}{l}\text { If } \\
\text { Id_pertanyaan= " } 13,14,15,16,17,18,\end{array}$ \\
\hline
\end{tabular}




\begin{tabular}{|c|c|}
\hline & $\begin{array}{l}19,20,21,22,23,24 " \\
\text { Then }[\text { Kesimpulan }]=\text { "CF Auditori" }\end{array}$ \\
\hline R3 & $\begin{array}{l}\text { If } \\
\text { Id_pertanyaan= " } 25,26,27,28,29,30, \\
31,32,33,34,35,36 " \\
\text { Then [Kesimpulan] = "CF Kinestetik" }\end{array}$ \\
\hline R4 & $\begin{array}{l}\text { If } \\
\text { CF Visual > CF Auditori AND CF } \\
\text { Visual }>\text { CF Kinestetik } \\
\text { Then [Kesimpulan] = "Visual" }\end{array}$ \\
\hline R5 & $\begin{array}{l}\text { If } \\
\text { CF Auditori > CF Visual AND CF } \\
\text { Auditori > CF Kinestetik } \\
\text { Then [Kesimpulan] = "Auditori" }\end{array}$ \\
\hline R6 & $\begin{array}{l}\text { If } \\
\text { CF Kinestetik }>\text { CF Auditori AND CF } \\
\text { Kinestetik > CF Visual Then } \\
{[\text { Kesimpulan] = "Kinestetik" }}\end{array}$ \\
\hline R7 & $\begin{array}{l}\text { If } \\
\text { Visual } \\
\text { Then [Anjuran] = "Visual" }\end{array}$ \\
\hline R8 & $\begin{array}{l}\text { If } \\
\text { Auditori } \\
\text { Then [Anjuran] = "Auditori" }\end{array}$ \\
\hline R9 & $\begin{array}{l}\text { If } \\
\text { kinestetik } \\
\text { Then [Anjuran] = "Kinestetik" }\end{array}$ \\
\hline
\end{tabular}

The last thing to do after the analysis phase and expert system design is the implementation and testing phase. At this stage an expert system is created based on the rules that have been made in the second stage. After that tested the expert system by measuring the accuracy of the expert system. Accuracy is calculated by comparing the results of the determination of learning styles by the expert system and the result of the determination of the learning style performed by the expert. Learning styles are determined after members consult with an expert system, then the expert system will provide the final learning style based on the greatest certainty factor value.

\section{RESULT AND DISCUSSION}

The tests were conducted with reference to the questionnaire to determine the learning modalities in the BPP education consulting bureau. The questionnaire data used in this testing process consisted of 53 data. The respondents who filled in the questionnaire were students and junior high school students at school $\mathrm{X}$, where the age range of respondents ranged from 12 years old to
14 years old. From 53 data it is known that the respondents male gender amounted to 33 people and women amounted to 20 people. The tests were conducted with a child psychology expert at the BPP education consultancy. The device used in testing expert system is a Samsung laptop with 300E5EV / 300343V / 270E4EV / 2470EV system model, 4 GB RAM capacity, and Intel Core i3 Processor.

Furthermore, the results of the questionnaire are matched with the results obtained from expert systems that have been made. The method of consultation used is divided into three methods, namely interview through questionnaire, examination of questionnaire results, determine the results of questionnaires with appropriate modalities. The method adopts the workings or methods of educational psychologist in the inner $\mathrm{X}$ consulting firm Provide consultation to the patient. Each consultation method has characters that then each character is paired with modalities and given a certainty factor value in accordance with the assessment of the expert or educational psychologist. In general, the method of consultation on the system is the same as the manual, only that distinguishes the value of certainty factor. Value certainty factor is needed to determine the value of certainty an expert. So with so the results of the consultation will be more valid.

1) Analysis of Test Results

TABLE 4. TEST RESULT DATA

\begin{tabular}{|c|c|c|c|c|c|c|c|}
\hline \multirow{2}{*}{ No } & \multirow{2}{*}{ id } & \multicolumn{3}{|c|}{ Nilai CF Sistem } & \multicolumn{3}{|c|}{ Nilai Score Manual } \\
\cline { 3 - 8 } & & $\mathrm{V}$ & $\mathrm{A}$ & $\mathrm{K}$ & $\mathrm{V}$ & $\mathrm{A}$ & $\mathrm{K}$ \\
\hline 1 & 2 & 0.953 & 0.998 & 0.979 & 12 & 17 & 15 \\
\hline 2 & 3 & 0.809 & 0.873 & 0.977 & 10 & 18 & 16 \\
\hline 3 & 11 & 0.843 & 0.888 & 0.671 & 8 & 7 & 7 \\
\hline 4 & 4 & 0.654 & 0.908 & 0.981 & 8 & 9 & 13 \\
\hline 5 & 5 & 0.964 & 0.997 & 0.917 & 10 & 17 & 13 \\
\hline 6 & 6 & 0.953 & 0.843 & 0.968 & 14 & 8 & 15 \\
\hline 7 & 7 & 0.991 & 0.967 & 0.997 & 15 & 8 & 19 \\
\hline 8 & 8 & 0.783 & 1.000 & 0.931 & 8 & 20 & 12 \\
\hline 9 & 10 & 0.906 & 0.970 & 0.866 & 9 & 12 & 8 \\
\hline 10 & 12 & 0.987 & 0.873 & 0.902 & 11 & 8 & 12 \\
\hline 11 & 13 & 0.978 & 0.996 & 0.967 & 14 & 14 & 13 \\
\hline 12 & 15 & 0.979 & 0.985 & 0.941 & 14 & 14 & 12 \\
\hline 13 & 20 & 0.988 & 0.971 & 0.988 & 16 & 10 & 16 \\
\hline 14 & 46 & 0.971 & 0.978 & 0.898 & 11 & 11 & 10 \\
\hline
\end{tabular}




\begin{tabular}{|c|c|c|c|c|c|c|c|}
\hline 15 & 47 & 0.972 & 0.994 & 0.983 & 14 & 13 & 14 \\
\hline 16 & 48 & 0.997 & 0.970 & 0.996 & 18 & 12 & 18 \\
\hline 17 & 14 & 0.995 & 0.991 & 0.986 & 16 & 14 & 15 \\
\hline 18 & 16 & 0.992 & 0.980 & 0.975 & 17 & 11 & 13 \\
\hline 19 & 17 & 0.934 & 0.928 & 0.892 & 11 & 8 & 9 \\
\hline 20 & 18 & 0.981 & 0.951 & 0.993 & 14 & 10 & 18 \\
\hline 21 & 19 & 0.998 & 0.926 & 0.969 & 20 & 10 & 14 \\
\hline 22 & 21 & 0.997 & 0.978 & 0.949 & 17 & 11 & 11 \\
\hline 23 & 22 & 0.968 & 0.997 & 0.963 & 12 & 16 & 14 \\
\hline 24 & 23 & 0.950 & 0.992 & 0.945 & 10 & 14 & 11 \\
\hline 25 & 24 & 0.937 & 0.998 & 0.910 & 12 & 16 & 11 \\
\hline 26 & 25 & 0.942 & 0.965 & 0.982 & 4 & 11 & 16 \\
\hline 27 & 26 & 0.991 & 0.991 & 0.972 & 18 & 15 & 14 \\
\hline 28 & 27 & 0.996 & 0.994 & 0.965 & 18 & 16 & 14 \\
\hline 29 & 28 & 0.945 & 0.969 & 0.989 & 13 & 11 & 14 \\
\hline 30 & 29 & 0.963 & 0.995 & 0.910 & 15 & 17 & 12 \\
\hline 31 & 30 & 0.982 & 0.956 & 0.929 & 15 & 10 & 10 \\
\hline 32 & 31 & 0.980 & 0.841 & 0.984 & 15 & 7 & 13 \\
\hline 33 & 32 & 0.949 & 0.961 & 0.905 & 14 & 11 & 11 \\
\hline 34 & 33 & 0.894 & 0.994 & 0.992 & 11 & 16 & 18 \\
\hline 35 & 34 & 0.989 & 0.963 & 0.979 & 15 & 10 & 16 \\
\hline 36 & 35 & 0.982 & 0.994 & 0.947 & 15 & 16 & 15 \\
\hline 37 & 36 & 0.967 & 0.882 & 0.691 & 16 & 10 & 8 \\
\hline 38 & 37 & 0.834 & 0.999 & 0.981 & 9 & 18 & 13 \\
\hline 39 & 38 & 0.928 & 0.999 & 0.992 & 12 & 17 & 15 \\
\hline 40 & 39 & 0.919 & 0.994 & 0.961 & 10 & 8 & 16 \\
\hline 41 & 41 & 0.994 & 0.987 & 0.976 & 17 & 11 & 14 \\
\hline 42 & 42 & 0.981 & 0.996 & 0.982 & 14 & 15 & 14 \\
\hline 43 & 43 & 0.990 & 0.991 & 0.934 & 15 & 13 & 12 \\
\hline 44 & 44 & 0.958 & 0.949 & 0.576 & 12 & 7 & 7 \\
\hline 45 & 45 & 0.917 & 0.995 & 0.766 & 8 & 14 & 8 \\
\hline 46 & 49 & 0.969 & 0.988 & 0.802 & 14 & 15 & 10 \\
\hline 47 & 50 & 0.980 & 0.999 & 0.968 & 14 & 17 & 13 \\
\hline 48 & 51 & 0.988 & 0.991 & 0.919 & 14 & 12 & 10 \\
\hline 49 & 52 & 0.982 & 0.983 & 0.991 & 15 & 12 & 16 \\
\hline 50 & 53 & 0.979 & 0.934 & 0.975 & 12 & 8 & 15 \\
\hline
\end{tabular}

Based on the data in Table 4 above, the result of the manual calculation process will allow members to have the same modality value, this can be seen in accordance with the test results on the orange row in table 4 above, ie the 11 th row up to the 16th row. This is because the results on manual calculations will only produce integers. Based on the data table above, then the results of the analysis are as follows:

1. The 11 th row shows that visual modalities $=$ 14 , auditory $=14$, and kinesthetic $=13$.

2. The 12th line shows that the result of visual value $=14$, auditory $=14$ and kinesthetic $=12$.

3. The 13th row of the same value is shown in the visual and kinesthetic modalities of 16 .

4. The 14th row of the same value is shown in the visual and auditory modalities of 11 .

5. Whereas the 15 th row of the same value is shown in visual and kinesthetic modalities with a value of 14 .

6. Similarly, the 16th row of the same value is shown also in the visual and kinesthetic modalities of 18 .

Based on the data in table 4, that the similarity of values between visual and auditory modalities, indicates that the process of consultation manually there is still uncertainty in determining the modalities, therefore the judgment of an expert is needed in determining this.

In contrast to the value of consultation testing results using the system. From the data in table 4above can be explained that each member who has consulted using the system, then of the three learning modalities will only be obtained 1 modalities with the highest value. Still with the data in Table 4 , ie on the 11 th row data up to the 16 th row by consulting testing using the system. On the 11 th row shows that the result of visual modality value $=0.9780848$, auditory $=0.9964217$, and kinestetik $=0.9674077$, so it can be concluded that the learning modality of the member is auditory with the highest value of 0.9964217 . While the calculation result of modality value on line 12 shows that visual modality $=0.9789614$, auditory $=$ 0.9853434 , and kinestetik $=0.9413737$, it can be determined that the learning modality of the member is auditory with the highest value is 0.9853434 . Likewise, the highest value at the 13th row up to the 16th row, the highest $\mathrm{CF}$ value is sequentially shown in kinesthetic modalities with $\mathrm{CF}=0.98815$, auditory modality with $\mathrm{CF}=$ 0.97798 , auditory modality with $\mathrm{CF}=0.99449$, and visual modalities with $\mathrm{CF}=0.99716$.

The thing that makes this expert system can show the highest value of the three modalities is because of the value of $\mathrm{CF}$ obtained from an expert. It has been previously explained that what distinguishes the consultation results from the system and manual is the process. In making this expert system, the value of this expert $\mathrm{CF}$ is indispensable in determining the priority of each child's character to show the most appropriate modalities with the child. Then the value of CF is 
used in the calculation of CF Combination process in accordance with the formula and rules that have been determined. In contrast to that done manually is by the process score. Score process can be used if the final score is no similarity between one modality with other modalities. But if the case is like the previous explanation, then the score alone can not prove with certainty that the result of the modalities with the score can indicate that the modalities are appropriate.

The next analysis will be addressed on the red line. On that line there is a difference in modal outcomes chosen after consultation with the system and manually. The existence of this difference is caused by the value of CF in the system while the value of $C F$ is not present in the conventional questionnaire. The system has been explained that the value of $\mathrm{CF}$ is important to determine the priority criteria of each modality. This conventional consultation uses a scoring system, in which there is no priority between one character and another, thus causing a difference with the process on the system. Therefore of the 53 questionnaires, 8 different data are obtained if done using the system. The results of this test indicate that expert system development to determine the learning modalities according to the personality of the child by using forward chaining method is in accordance with the needs of BPP education consultation bureaus and can be implemented in the bureau.

\section{CONCLUSION}

Conclusions drawn from the design and development of expert system application design to determine the modalities or learning styles based on the child's personality, among others:

1) This expert system can make it easy for the expert (child psychology education) and its members to know the modalities or learning styles in accordance with his personality

2) The system can provide advice in accordance with the modalities or learning styles of members who have consulted

3) The method of forward chaining can be implemented in making the expert system of determining the learning modalities in accordance with the personality of the child.
In addition, Based on the results of the analysis of tests that have been done, it can be concluded that with the value of certainty factor $(\mathrm{CF})$ or the value of expert certainty, the system is able to provide more valid results in determining the learning modalities of children. This can be proved by the value of $\mathrm{CF}$ of the three modalities will only produce the highest value, because each criterion has its own priority, resulting in different calculations. In contrast to the results of consultations conducted conventionally, which only refers to the final result of the members score alone regardless of the priority criteria. So that does not close the possibility of the end result score sometimes have in common. If 2 modalities have the same final score, then the expert gives both recommendations from both modalities.

\section{REFERENCES}

[1] Arisandi, D. And Saputra, A., 2015. Aplikasi Sistem Pakar Untuk Menentukan Gaya Belajar Anak Usia Sekolah Dasar. Digital Zone: Jurnal Teknologi Informasi Dan Komunikasi, 6(2).

[2] Broto, A. S., 2010. Perancangan Dan Implementasi Sistem Pakar Untuk Analisa Penyakit Dalam, Semarang: S.N.

[3] Dony Novaliendry. 2015. The Expert System Application For Diagnosing Human Vitamin Deficiency Through Forward Chaining Method. IEEE, P. 53.

[4] T.Sutojo., 2011. Kecerdasan Buatan. Yogyakarta: ANDI.

[5] Sachin Kamley, S. J. A. R. T., 2016. Performance Comparison Between Forward Chaining And Backward Chaining Rule Based Expert System Approaches Over Global Stock Exchanges. International Journal Of Computer Science AndInformation Security, Volume 14, P. 74.

[6] Lokman .2014. Personal Financial Planner: A Mobile Application That Implementation Forward Chaining Technique For Notification Mechanism.IEEE Symposium On Computer Application \& Industrial Electronics (ISCAIE),P. 65

[7] Mohammad Mudassar. 2016. Computing The Impact Of Security Attack On Network Using Fuzzy Logic. International Research Journal Of EngineeringAnd Technology (IRJET), P. 1582.

[8] Norah Md Noor, 2014. Video Based Learning Embedded With Cognitive Load Theory: Visual, Auditory, And Kinaesthetic Learners' Perspectives.International Conference On Teaching And Learning In Computing And Engineering, P. 59. 